medRxiv preprint doi: https://doi.org/10.1101/2021.05.13.21257046; this version posted May 17, 2021. The copyright holder for this preprint

(which was not certified by peer review) is the author/funder, who has granted medRxiv a license to display the preprint in perpetuity.

This article is a US Government work. It is not subject to copyright under 17 USC 105 and is also made available for use under a CCO license.

\title{
ABCDEF Bundle Implementation: The influence of access to bundle-enhancing supplies and equipment
}

Alvin D. Jeffery PhD, RN, CCRN-K, NPD-BC FNP-BC ${ }^{1,2,3}$, Jennifer A. Werthman PhD, $\mathrm{RN}^{1}$, Valerie Danesh $\mathrm{PhD}, \mathrm{RN}{ }^{4,5}$, Mary S. Dietrich PhD ${ }^{2,3}$, Lorraine C. Mion PhD, RN ${ }^{6,7}$, Leanne M. Boehm PhD, RN, ACNS-BC ${ }^{2,8}$

${ }^{1}$ Geriatric Research, Education and Clinical Center (GRECC), VA Tennessee Valley Healthcare System, Nashville, TN, USA

${ }^{2}$ School of Nursing, Vanderbilt University, Nashville, TN, USA

${ }^{3}$ Department of Biomedical Informatics, Vanderbilt University Medical Center, Nashville, TN, USA

${ }^{4}$ Baylor Scott \& White Health Research Institute, Dallas, TX, USA

${ }^{5}$ School of Nursing, University of Texas at Austin, Austin, TX

${ }^{6}$ College of Nursing, The Ohio State University, Columbus, OH, USA

${ }^{7}$ Center for Healthy Aging, Self Management, and Complex Care, The Ohio State University, Columbus, OH, USA

${ }^{8}$ Critical Illness, Brain Dysfunction, and Survivorship Center, Vanderbilt University Medical Center, Nashville, TN, USA

\begin{abstract}
Importance: The $A B C D E F$ bundle is a guideline-recommended framework for implementing evidence-based practices in the Intensive Care Unit (ICU), but it is underutilized across the world.
\end{abstract}

Objective: Describe the physical environment factors (i.e., availability, accessibility) of bundleenhancing items in units implementing the bundle and the influence of physical environment on bundle adherence.

Design, Setting, and Participants: This multicenter, exploratory, cross-sectional study used data from two ICU-based randomized controlled trials (RCTs) (NCT01211522 and NCT01739933) that measured daily bundle adherence. The study included 10 medical and surgical ICUs in 6 academic medical centers in the continental United States. Adults with qualifying respiratory failure and/or septic shock (e.g., mechanical ventilation, vasopressor use) were included in the RCTs. Unit- and patient-level data collection occurred between 2011 and 2016. We conducted hierarchical logistic regression models using Frequentist and Bayesian frameworks.

Exposure: The ABCDE bundle (ㄹwakening and $\underline{B}$ reathing trial Coordination, Delirium assessment/management, Early mobility) was recommended standard of care for RCT patients and adherence tracked daily.

Measure(s): The primary outcome was adherence to the full bundle and the early mobility bundle component as identified from daily adherence documentation ( $n=751$ patient observations). Unit-level measures included minimum and maximum distances to 25 bundleenhancing items and the relationship to bundle adherence.

Results: In all cases, mechanical ventilation was associated with decreased bundle adherence. Some of the models suggested the following variables were also influential: age (older associated with decreased adherence), unit size (larger associated with decreased adherence), and a standard walker (presence associated with increased adherence).

Conclusions and Relevance: Both unit- and patient-level barriers influenced full bundle and early mobility implementation. There is potential benefit of physical proximity to essential items for ABCDEF bundle and early mobility adherence. Future studies with larger sample sizes should explore how equipment location and availability influences practice. 
medRxiv preprint doi: https://doi.org/10.1101/2021.05.13.21257046; this version posted May 17, 2021. The copyright holder for this preprint

(which was not certified by peer review) is the author/funder, who has granted medRxiv a license to display the preprint in perpetuity.

This article is a US Government work. It is not subject to copyright under 17 USC 105 and is also made available for use under a CCO license.

\section{Key Points}

Question: Does the physical environment, specifically the availability and accessibility of ABCDEF bundle-enhancing items, influence bundle adherence?

Findings: In this cross-sectional study in 10 units evaluating ABCDEF bundle adherence across 751 patient observations, units with access to a standard walker were significantly more likely to provide bundled care. Across all models, patients who were on the ventilator or older were significantly less likely to received bundled care.

Meaning: Both unit- and patient-level factors influence $A B C D E F$ bundle implementation and amenable targets for implementation strategy development. 
medRxiv preprint doi: https://doi.org/10.1101/2021.05.13.21257046; this version posted May 17, 2021. The copyright holder for this preprint (which was not certified by peer review) is the author/funder, who has granted medRxiv a license to display the preprint in perpetuity. This article is a US Government work. It is not subject to copyright under 17 USC 105 and is also made available for use under a CCO license.

\section{Introduction}

The ABCDEF bundle (소ssess, prevent and manage pain; $\underline{B}$ oth spontaneous awakening

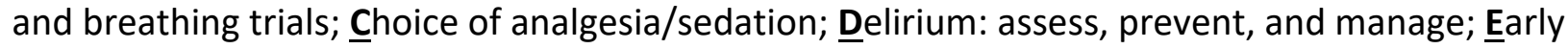
mobility; Family engagement and empowerment) is a guideline-recommended, evidence-based approach to organizing Intensive Care Unit (ICU) people, processes, and technology for improved care of the critically ill patient. ${ }^{1-3} A B C D E F$ bundle implementation is associated with reduced delirium, ventilator, ICU, and hospital days; improved survival; and increased likelihood of early mobilization and restraint-free care..$^{4-6}$ Despite guideline recommendations, the bundle is still underutilized in ICUs across the world. ${ }^{7}$ Organizational structure and process factors (e.g., physical environment, staffing, autonomy, workload) have commonly been identified as barriers to bundle implementation..$^{8-11}$

Reason's Human Errors conceptualization recognizes the influence of latent conditions (i.e., dormant conditions that only become evident with triggering factors). ${ }^{12}$ In the context of $A B C D E F$ implementation, the latent conditions of the physical environment may influence behavioral outcomes. The physical environment, or physical space, of the ICU setting includes the nursing unit configuration, building-related characteristics (e.g., fixtures, dialysis connection placements, distance to equipment storage rooms), and the built environment of modifiable characteristics such as the presence of ceiling lifts, the reach distance from bed to tray table, and the visibility of mobility equipment.

The relationship between the physical environment and care delivery variability has been explored in diverse healthcare settings and patient populations. For example, studies of furniture placement proximity affect interpersonal distance and subsequent self-disclosure during patient-provider history interviews. ${ }^{13}$ In acute care settings, time-motion studies 
medRxiv preprint doi: https://doi.org/10.1101/2021.05.13.21257046; this version posted May 17, 2021. The copyright holder for this preprint (which was not certified by peer review) is the author/funder, who has granted medRxiv a license to display the preprint in perpetuity. This article is a US Government work. It is not subject to copyright under 17 USC 105 and is also made available for use under a CCO license.

assessing the variability of care between hospitalized patients with and without contact isolation precautions suggest that donning additional isolation gowns with each patient room entry are associated with adverse effects. ${ }^{14}$ Adverse effects of contact isolation include care variability such as decreases in patient-clinician contact and decreases in patient satisfaction. ${ }^{15}$, ${ }^{16}$ Variability associated with the change in the physical environment (isolation gowning requirement) is associated with increases in non-infectious adverse events and higher rates of medication errors. ${ }^{15,17,18}$ To date, associations between the physical environment and ABCDEF implementation uptake at the nursing shift-level has not been explored.

The aim of this study is to describe the physical environment factors (i.e., availability, accessibility) of $A B C D E F$ bundle-enhancing items in units implementing the bundle and the influence of physical environment on bundle adherence.

\section{Materials and Methods}

This is an exploratory multicenter cross-sectional study conducted with sites participating in two ICU-based randomized controlled trials (RCTs) (NCT01211522 and NCT01739933). Data collection occurred between 2011 and 2016. At the initiation of both studies, the bundle was still an evolving framework for critical care open to evidence-based modification. At the time of these RCTs, we applied the original ABCDE bundle framework

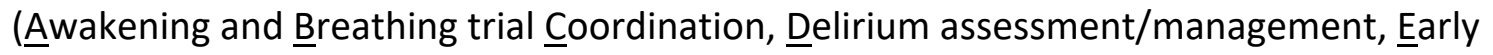
mobility) and use this term for our materials and methods description. ${ }^{19,20}$ The bundle has since been modified to include current critical care guidelines (i.e., ABCDEF bundle, see www.iculiberation.org and www.icudelirium.org). ${ }^{1,2}$ Ethical approval was obtained from the institutional review board at each of the participating centers. 
medRxiv preprint doi: https://doi.org/10.1101/2021.05.13.21257046; this version posted May 17, 2021. The copyright holder for this preprint (which was not certified by peer review) is the author/funder, who has granted medRxiv a license to display the preprint in perpetuity. This article is a US Government work. It is not subject to copyright under 17 USC 105 and is also made available for use under a CCO license.

\section{Setting \& Sample}

We obtained information from medical and surgical ICUs $(n=10)$ at six academic medical centers across the continental United States. Hospital size ranged from 175 to 1,541 licensed beds and 10 to 40 beds per ICU. Size of participating units ranged from 987 to 3,412 square meters $\left(\mathrm{m}^{2}\right)$ (median=1,981 $\left.\mathrm{m}^{2}\right)$.

Prospective observational patient data was obtained from two ICU-based randomized controlled trials (RCTs) (NCT01211522 and NCT01739933) that employed the bundle as standard of care and measured daily bundle adherence. ${ }^{21,22}$ Adults with qualifying respiratory failure and/or septic shock (e.g., mechanical ventilation, vasopressor use) were included in the RCTs. Patients with severe cognitive impairment, drug allergy (e.g., haloperidol, propofol), moribund state, cardiac arrythmias (i.e., Torsades de Pointes, $2^{\text {nd }}$ or $3^{\text {rd }}$ degree heart block), unable to speak or understand English, or incarcerated were excluded. Patient screening, randomization, follow-up and analysis are published in the parent RCT reports. ${ }^{21,22}$

\section{Variables and Measures}

We generated a comprehensive list of supplies and equipment (25 items) for the completion of $A B C D E$ bundle components through communication with clinicians providing critical care. We measured the minimum and maximum distances (in meters) from a head of bed closest to and farthest from each of the 25 bundle-enhancing items.

ABCDE bundle adherence is defined as completing all 5 components on ICU days requiring mechanical ventilation (MV) and completion of delirium assessment/management and early mobility (DE) components on MV-free days. We calculated full bundle adherence for the entire period of MV ICU days as [(days of full bundle adherence)/(total MV ICU days)]. ${ }^{9}$ We 
medRxiv preprint doi: https://doi.org/10.1101/2021.05.13.21257046; this version posted May 17, 2021. The copyright holder for this preprint (which was not certified by peer review) is the author/funder, who has granted medRxiv a license to display the preprint in perpetuity. This article is a US Government work. It is not subject to copyright under 17 USC 105 and is also made available for use under a CCO license.

independently calculated adherence to the E bundle component on MV days and MV-free days using the same equation.

\section{Procedures}

The principal investigator (LMB) personally visited each site to meet individually with the leadership of participating units and collect measurements. LMB operated a measuring wheel to capture exact distances for the minimum and maximum distances from the closest and farthest head of bed to each of the 25 bundle-enhancing items.

The ICU teams completed the ABCDE bundle at their discretion, guided by a standardized protocol as part of the parent RCTs. ${ }^{21,22}$ The investigators were not responsible for $A B C D E$ bundle performance. An ABCDE bundle checklist was placed at the patient's bedside and completed by the nurse or other healthcare professional each calendar day for RCT participants. ${ }^{9}$ Study staff distributed, collected, and recorded checklists daily. We collected and managed all study data using Research Electronic Data Capture (REDCap) tools hosted at Vanderbilt University. ${ }^{23}$

\section{Statistical Methods}

We developed two hierarchical logistic regression models using Frequentist and Bayesian frameworks with predictors comprising whether a patient was on a ventilator on a given day, the patient's age and body mass index, and geospatial measurements (unit size and distances to 25 unique pieces of equipment). The first assumed a binary present/absent method for unit equipment. The second included the actual distances from head of bed to specific unit equipment. In all models, we nested patient-days within patients and patients within units (i.e., 3-level hierarchy). 
medRxiv preprint doi: https://doi.org/10.1101/2021.05.13.21257046; this version posted May 17, 2021. The copyright holder for this preprint (which was not certified by peer review) is the author/funder, who has granted medRxiv a license to display the preprint in perpetuity. This article is a US Government work. It is not subject to copyright under 17 USC 105 and is also made available for use under a CCO license.

We modeled two primary outcomes: (1) adherence with the full bundle and (2) adherence with the early mobility [E] component, given it had the largest variance of all components and 23 of the 25 items were directly associated with early mobility. For units that did not have a piece of equipment, we imputed the missing values with two methods: (1) representing missing values as 0 and observed values as 1 - the binary models and (2) replacing missing values with twice the maximum observed value to conceptually represent the equipment being even farther away - the continuous models. We imputed missing data for height (5.7\% missing) and weight ( $4.8 \%$ missing) using the Iterativelmputer function from Python's scikit-learn library. As a final pre-processing step, we scaled all non-binary, numeric variables to have a mean of 0 and variance of 1 . Given the large number of predictors $(p=29)$ for the relatively small number of patient observations $(n=751)$, we conducted a redundancy analysis using subject matter expertise, examining bivariate correlations coefficients, and building regression models to determine which variables could be predicted from remaining variables. This dimensionality reduction process resulted in the inclusion of 6 predictors in the binary models and 7 predictors in the continuous models (see eFigures 1-4 and eTable 1 in the Supplement for further details).

For the Frequentist models, we used the Ime4 package in R Studio (1.1.463, R Core Team, 2015) (https://cran.r-project.org/web/packages/Ime4/vignettes/Imer.pdf). For the Bayesian models, we used PYMC3 (version 3.7) in Python (version 3.6.7). We used the No UTurn Sampler suggested by Hoffman and Gelman (2014), which is a variation of the Hamiltonian Monte Carlo simulation method that allows for automatic tuning of step size and number. ${ }^{24} \mathrm{We}$ developed models with uninformative priors (normal distributions with mean of 0 and standard 
medRxiv preprint doi: https://doi.org/10.1101/2021.05.13.21257046; this version posted May 17, 2021. The copyright holder for this preprint (which was not certified by peer review) is the author/funder, who has granted medRxiv a license to display the preprint in perpetuity. This article is a US Government work. It is not subject to copyright under 17 USC 105 and is also made available for use under a CCO license.

deviations pulling from a half-Cauchy distribution with beta value of 5) and weakly informative priors (normal distributions with mean of -1 (for patient-level predictors and for equipment in the continuous models) or +1 (for equipment in the binary models) and standard deviations pulling from a half-Cauchy distribution with beta value of 2). We adjusted the number of tuning steps, iterations, and acceptance rates to optimize sampling chain convergence, Gelman-Rubin R-hat values, and Geweke z-scores.

\section{Results}

The sample represents 751 patient observations across 105 patients within 10 different ICUs. The availability of ABCDEF-enhancing supplies and equipment ranged from 8-15 items across units. All units had electronic charts, bag valve masks, oxygen tubing, positive end expiratory pressure (PEEP) valves, and automated medication dispensing systems. The most commonly available bundle-enhancing items were standard walkers ( $n=9$ units), ceiling lifts ( $n=7$ units), and recliner chairs ( $n=7$ units). The least commonly available ( $n=1-2$ units) bundleenhancing items were sit-to-stand aid, bariatric chair, portable ventilator, portable monitor, turning straps, stretch bands, and nonpharmacologic delirium aids. Table 1 provides descriptive summaries for patient and unit level variables. Dot plot graphical comparisons of beta coefficients across the four best-fit models for each predictor type (i.e., binary and continuous) are found in Figure $\mathbf{1 a}$ and $\mathbf{1 b}$, and corresponding numerical details are found in Table $\mathbf{3}$ and

Table 4. Beta coefficient estimate density plots for the best-fit Bayesian models are found in the Supplement (eFigures 1-4).

\section{Full Bundle Adherence}


medRxiv preprint doi: https://doi.org/10.1101/2021.05.13.21257046; this version posted May 17, 2021. The copyright holder for this preprint (which was not certified by peer review) is the author/funder, who has granted medRxiv a license to display the preprint in perpetuity. This article is a US Government work. It is not subject to copyright under 17 USC 105 and is also made available for use under a CCO license.

In the Frequentist approach, both binary models for full bundle adherence and early mobility demonstrated better goodness of fit based on the Akaike information criterion (AIC) statistic (Table 2). Daily ventilator status and age were the only statistically significant predictors when modeling the outcome of full bundle adherence using various predictors in both the binary and continuous models (Table 3). Both variables had negative beta coefficients, indicating active mechanical ventilation and older age negatively influenced completion of the full bundle.

In the Bayesian approach, models with uninformative priors outperformed models with weakly-informative priors based on widely-applicable information criterion (WAIC) values (Table 2); therefore, primary findings are reported from models with uninformative priors. When using binary predictors, daily ventilator status, age, and availability of a standard walker had 95\% high probability densities (HPDs) excluding 0 (Table 3). When using continuous predictors, daily ventilator status had 95\% HPDs excluding 0 . The beta coefficients for daily ventilator status and age were negative, indicating decreased full bundle adherence on days the patient is receiving mechanical ventilation and among older patients. The beta coefficient for walker availability was positive, indicating increased full bundle adherence on units with walkers.

Early Mobility Adherence

For both binary and continuous models (Table 4), daily ventilator status was the only statistically significant predictor. Ventilator status had a negative regression weight, indicating active mechanical ventilation negatively influenced completion of early mobility. 
medRxiv preprint doi: https://doi.org/10.1101/2021.05.13.21257046; this version posted May 17, 2021. The copyright holder for this preprint (which was not certified by peer review) is the author/funder, who has granted medRxiv a license to display the preprint in perpetuity. This article is a US Government work. It is not subject to copyright under 17 USC 105 and is also made available for use under a CCO license.

In the Bayesian approach, models with uninformative priors outperformed models with weakly-informative priors when using binary predictors; conversely, models with weaklyinformative priors outperformed models with uninformative priors when using continuous predictors (Table 2). When using binary predictors, daily ventilator status, a unit's size, and availability of a walker had 95\% HPDs excluding 0 (Table 4). When using continuous predictors, daily ventilator status had 95\% HPDs excluding 0 . Similar to the full bundle adherence models, the beta coefficients were negative for daily ventilator status and positive for standard walker availability. The beta coefficient for unit size was negative, indicating decreased early mobility adherence on larger units.

\section{Clinical Interpretation}

Using variables that were statistically significant in the Frequentish approach or had HPDs excluding 0 in the Bayesian approach, one can convert the beta coefficients' point estimates from all models into odds ratio ranges to aid interpretation, which we have done here. Being on the ventilator is independently associated with a patient being 8-20 times less likely to receive the full bundle and 7-11 times less likely to receive the early mobility component of the budle. Having a standard walker on the unit is associated with a patient being 5 times more likely to receive the fulle bundle and 13 times more likely to receive the early mobility component of the bundle. For every 1-year increase in a patient's age the odds of receiving the full bundle are decreased by 33\%. According to only 1 model, for every 1 meter ${ }^{2}$ increase in the unit size, the odds of receiving the early mobility component of the bundle are decreased by $85 \%$.

\section{Discussion}


medRxiv preprint doi: https://doi.org/10.1101/2021.05.13.21257046; this version posted May 17, 2021. The copyright holder for this preprint (which was not certified by peer review) is the author/funder, who has granted medRxiv a license to display the preprint in perpetuity. This article is a US Government work. It is not subject to copyright under 17 USC 105 and is also made available for use under a CCO license.

We used multiple analytic models to examine the availability and accessibility of ABCDEF bundle-enhancing items in order to generate hypotheses about geospatial factors influencing bundle implementation. At the unit level, the presence of a standard walker was associated with full $A B C D E F$ bundle and early mobility adherence. Larger unit size $\left(\mathrm{m}^{2}\right)$ was associated with lower early mobility adherence. At the patient level, daily ventilator status was the only variable to consistently influence bundle adherence across all statistical models. Older age influenced the likelihood of receiving incomplete bundled care. Overall, the findings suggest the benefit of physical proximity to essential items for ABCDEF bundle and early mobility adherence.

Active mechanical ventilation was an important factor influencing both full bundle and early mobility adherence. Previous studies describe aversion to early mobility and ABCDEF bundle adherence due to perceived safety concerns or risk of adverse events (e.g., tube dislodgment, desaturation, fall). ${ }^{25,}{ }^{26}$ However, adverse events occurring with implementation of the $A B C D E F$ bundle and related components are reportedly low. ${ }^{5,27,28}$ Similarly, increases in patient age were associated with decreases in full bundle adherence. In addition to safety concerns, this could be due to biased perceptions of older people as frail with diminished intrinsic capacity (i.e., the physical and mental capacity of an individual). ${ }^{29}$ Diverse trajectories of aging means there is no typical older person (e.g., 90-year-old marathon runner [high intrinsic capacity] vs. 60-year-old bedbound individual [frail]); thus, intrinsic capacity exists along a continuum. ${ }^{29}$ To address potential patient-level barriers to implementation, strategies may include interventions that overcome clinician hesitance with performing bundled care and implementing intrinsic capacity assessments at admission to develop care plans (e.g., mobility level goal) that maintain baseline function and avoid age-related bias. 
medRxiv preprint doi: https://doi.org/10.1101/2021.05.13.21257046; this version posted May 17, 2021. The copyright holder for this preprint (which was not certified by peer review) is the author/funder, who has granted medRxiv a license to display the preprint in perpetuity. This article is a US Government work. It is not subject to copyright under 17 USC 105 and is also made available for use under a CCO license.

At the unit level, our analysis builds on existing time-motion studies of the nurse work environment. In medical-surgical nursing units, when patient room assignments are clustered in close proximity and walking distances are minimized, the number of nurse-patient interactions increases. ${ }^{30}$ Similarly, our findings demonstrate that the geospatial location of mobility-related equipment could also be associated with use for full bundle adherence. Characteristics of the physical environment, both fixed (e.g., unit size) and modifiable (e.g., accessibility of a portable patient lift), may contribute to structure and process factors influencing full bundle implementation.

Strengths of our study comprise the heterogenous representation of medical and surgical ICUs from geographically diverse medical centers as well as the use of multiple analytic methods for triangulation. Slowly gaining popularity in the biomedical literature, Bayesian analyses have the advantage of incorporating prior knowledge and do not introduce error inflation during multiple testing. Further, our findings can be used as prior distributions in future studies leveraging Bayesian statistics, which effectively reduces the sample size needed in the future.

Our study has limitations that warrant consideration. The sample size of 10 ICUs from 6 academic medical centers does not represent the majority of ICU contexts, but does represent a mix of geographic regions in the Northeast, Southeast, Midwest, Southwest, and Pacific Northwest United States. The small sample size also limits our ability to make causal inference and resulted in sparse and collinear data for some pieces of equipment, necessitating their removal during final analyses. Evaluating bundle adherence by augmenting structural physical 
medRxiv preprint doi: https://doi.org/10.1101/2021.05.13.21257046; this version posted May 17, 2021. The copyright holder for this preprint

(which was not certified by peer review) is the author/funder, who has granted medRxiv a license to display the preprint in perpetuity.

This article is a US Government work. It is not subject to copyright under 17 USC 105 and is also made available for use under a CCO license.

environment variables with process-related variables (e.g., team composition, staffing, and workflow) could also offer evidence-based insights for intervention development. ${ }^{31}$

\section{Conclusion}

We identified unit- and patient-level barriers that may influence full bundle and early mobility implementation. There may be benefit to physical proximity of bundle-enhancing items, but we are limited in our ability to make causal inferences about the physical environment and adherence. There is benefit in testing implementation strategies that address hesitancy of performing bundled care with critically ill patients and applying early assessment of a patient's intrinsic capacity. Future studies with larger sample sizes should explore how availability and accessibility (e.g., equipment location) could have implications to promote the implementation of evidence-based design. 
medRxiv preprint doi: https://doi.org/10.1101/2021.05.13.21257046; this version posted May 17, 2021. The copyright holder for this preprint

(which was not certified by peer review) is the author/funder, who has granted medRxiv a license to display the preprint in perpetuity.

This article is a US Government work. It is not subject to copyright under 17 USC 105 and is also made available for use under a CCO license.

\section{References}

1. Devlin JW, Skrobik Y, Gelinas C, et al. Clinical Practice Guidelines for the Prevention and Management of Pain, Agitation/Sedation, Delirium, Immobility, and Sleep Disruption in Adult Patients in the ICU. Crit Care Med. Sep 2018;46(9):e825-e873.

doi:10.1097/CCM.0000000000003299

2. Ely EW. The ABCDEF Bundle: Science and Philosophy of How ICU Liberation Serves Patients and Families. Crit Care Med. Feb 2017;45(2):321-330.

doi:10.1097/CCM.0000000000002175

3. Morandi A, Brummel NE, Ely EW. Sedation, delirium and mechanical ventilation: the 'ABCDE' approach. Curr Opin Crit Care. Feb 2011;17(1):43-9.

doi:10.1097/MCC.0b013e3283427243

4. Pun BT, Balas MC, Barnes-Daly MA, et al. Caring for Critically III Patients with the ABCDEF Bundle: Results of the ICU Liberation Collaborative in Over 15,000 Adults. Crit Care Med. Jan 2019;47(1):3-14. doi:10.1097/CCM.0000000000003482

5. Balas MC, Vasilevskis EE, Olsen KM, et al. Effectiveness and safety of the awakening and breathing coordination, delirium monitoring/management, and early exercise/mobility bundle. 2 Before-After. Crit Care Med. May 2014;42(5):1024-36. doi:10.1097/CCM.0000000000000129 6. Barnes-Daly MA, Phillips G, Ely EW. Improving Hospital Survival and Reducing Brain Dysfunction at Seven California Community Hospitals: Implementing PAD Guidelines Via the ABCDEF Bundle in 6,064 Patients. Crit Care Med. Feb 2017;45(2):171-178. doi:10.1097/CCM.0000000000002149 
medRxiv preprint doi: https://doi.org/10.1101/2021.05.13.21257046; this version posted May 17, 2021. The copyright holder for this preprint

(which was not certified by peer review) is the author/funder, who has granted medRxiv a license to display the preprint in perpetuity.

This article is a US Government work. It is not subject to copyright under 17 USC 105 and is also made available

7. Morandi A, Piva S, Ely EW, et al. Worldwide Survey of the "Assessing Pain, Both

Spontaneous Awakening and Breathing Trials, Choice of Drugs, Delirium

Monitoring/Management, Early Exercise/Mobility, and Family Empowerment" (ABCDEF)

Bundle. Crit Care Med. Nov 2017;45(11):e1111-e1122. doi:10.1097/CCM.0000000000002640

8. Boehm LM, Vasilevskis EE, Dietrich MS, et al. Organizational Domains and Variation in

Attitudes of Intensive Care Providers Toward the ABCDE Bundle. Am J Crit Care. May

2017;26(3):e18-e28. doi:10.4037/ajcc2017297

9. Boehm LM, Dietrich MS, Vasilevskis EE, et al. Perceptions of Workload Burden and

Adherence to ABCDE Bundle Among Intensive Care Providers. Am J Crit Care. Jul

2017;26(4):e38-e47. doi:10.4037/ajcc2017544

10. Costa DK, White MR, Ginier E, et al. Identifying barriers to delivering the awakening and breathing coordination, delirium, and early exercise/mobility bundle to minimize adverse outcomes for mechanically ventilated patients: a systematic review. Chest. 2017;152(2):304-

311.

11. Balas MC, Pun BT, Pasero C, et al. Common Challenges to Effective ABCDEF Bundle Implementation: The ICU Liberation Campaign Experience. Crit care nurse. 01 Feb 2019;39(1):46-60.

12. Reason J. Understanding adverse events: human factors. Qual in Health Care. 1995;4(2):80. doi:10.1136/qshc. 4.2 .80

13. Okken V, van Rompay $T$, Pruyn A. Exploring space in the consultation room:

Environmental influences during patient-physician interaction. 3 Cohort Case-Control. J Health

Commun. 2012;17(4):397-412. doi:10.1080/10810730.2011.626498 
medRxiv preprint doi: https://doi.org/10.1101/2021.05.13.21257046; this version posted May 17, 2021. The copyright holder for this preprint (which was not certified by peer review) is the author/funder, who has granted medRxiv a license to display the preprint in perpetuity. This article is a US Government work. It is not subject to copyright under 17 USC 105 and is also made available for use under a CCO license.

14. Abad C, Fearday A, Safdar N. Adverse effects of isolation in hospitalised patients: A systematic review. J Hosp Infect. 1/1/2010 2010;76(2):97-102.

doi:10.1016/j.jhin.2010.04.027

15. Morgan DJ, Diekema DJ, Sepkowitz K, Perencevich EN. Adverse outcomes associated with contact precautions: A review of the literature. Am J Infect Control. 2009;37(2):85-93. doi:10.1016/j.ajic.2008.04.257

16. Stelfox HT, Bates DW, Redelmeier DA. Safety of Patients Isolated for Infection Control. Je Am Med Assoc. 2003;290(14):1899-1905. doi:10.1001/jama.290.14.1899

17. Sanghera IS, Franklin BD, Dhillon S. The attitudes and beliefs of healthcare professionals on the causes and reporting of medication errors in a UK Intensive care unit. Anaesthesia. Jan 2007;62(1):53-61. doi:10.1111/j.1365-2044.2006.04858.x

18. Zahar J, Garrouste-Orgeas M, Vesin A, et al. Impact of contact isolation for multidrugresistant organisms on the occurrence of medical errors and adverse events. Intensive Care Med. 2013;39(12):2153-2160. doi:10.1007/s00134-013-3071-0

19. Balas MC, Vasilevskis EE, Burke WJ, et al. Critical Care Nurses' Role in Implementing the "ABCDE Bundle" Into Practice. Crit Care Nurse. Apr 2012;32(2):35-47. doi:10.4037/ccn2012229

20. Vasilevskis EE, Pandharipande PP, Girard TD, Ely EW. A screening, prevention, and restoration model for saving the injured brain in intensive care unit survivors. Crit Care Med. Oct 2010;38(10 Suppl):S683-91. doi:10.1097/CCM.0b013e3181f245d3

21. Girard TD, Exline MC, Carson SS, et al. Haloperidol and Ziprasidone for Treatment of Delirium in Critical Illness. N Engl J Med. Dec 27 2018;379(26):2506-2516. doi:10.1056/NEJMoa1808217 
medRxiv preprint doi: https://doi.org/10.1101/2021.05.13.21257046; this version posted May 17, 2021. The copyright holder for this preprint

(which was not certified by peer review) is the author/funder, who has granted medRxiv a license to display the preprint in perpetuity.

This article is a US Government work. It is not subject to copyright under 17 USC 105 and is also made available for use under a CCO license.

22. Hughes CG, Mailloux PT, Devlin JW, et al. Dexmedetomidine or Propofol for Sedation in Mechanically Ventilated Adults with Sepsis. N Engl J Med. 2021;doi:10.1056/NEJMoa2024922

23. Harris PA, Taylor R, Thielke R, Payne J, Gonzalez N, Conde JG. Research electronic data capture (REDCap)--a metadata-driven methodology and workflow process for providing translational research informatics support. J Biomed Inform. Apr 2009;42(2):377-81. doi:10.1016/j.jbi.2008.08.010

24. Hoffman MD, Gelman A. The No-U-turn sampler: adaptively setting path lengths in Hamiltonian Monte Carlo. J Mach Learn Res. 2014. p. 1593-1623.

25. Boehm LM, Vasilevskis EE, Mion LC. Interprofessional Perspectives on ABCDE Bundle Implementation: A Focus Group Study. Dimens Crit Care Nurs. Nov/Dec 2016;35(6):339-347. doi:10.1097/DCC.0000000000000208

26. Boehm LM, Lauderdale J, Garrett AN, Piras SE. A multisite study of multidisciplinary ICU team member beliefs toward early mobility. Heart \& lung. 2021;50(1):214-219. doi:10.1016/j.hrtIng.2020.09.021

27. Bailey P, Thomsen GE, Spuhler VJ, et al. Early activity is feasible and safe in respiratory failure patients. Crit Care Med. Jan 2007;35(1):139-45.

doi:10.1097/01.CCM.0000251130.69568.87

28. Girard TD, Kress JP, Fuchs BD, et al. Efficacy and safety of a paired sedation and ventilator weaning protocol for mechanically ventilated patients in intensive care (Awakening and Breathing Controlled trial): a randomised controlled trial. Lancet. Jan 12 2008;371(9607):126-34. doi:10.1016/S0140-6736(08)60105-1 
medRxiv preprint doi: https://doi.org/10.1101/2021.05.13.21257046; this version posted May 17, 2021. The copyright holder for this preprint

(which was not certified by peer review) is the author/funder, who has granted medRxiv a license to display the preprint in perpetuity.

This article is a US Government work. It is not subject to copyright under 17 USC 105 and is also made available for use under a CCO license.

29. Wang J, Boehm L, Mion LC. Intrinsic capacity in older hospitalized adults: Implications for nursing practice. Geriatric nursing. 2017;38(4):359-361.

doi:10.1016/j.gerinurse.2017.06.008

30. Hendrich A, Chow MP, Bafna S, Choudhary R, Heo Y, Skierczynski BA. Unit-related factors that affect nursing time with patients: spatial analysis of the time and motion study. HERD. Winter 2009;2(2):5-20.

31. Costa DK, Valley TS, Miller MA, et al. ICU team composition and its association with ABCDE implementation in a quality collaborative. J Crit Care. Sep 28 2017;44:1-6.

doi:10.1016/j.jcrc.2017.09.180 
medRxiv preprint doi: https://doi.org/10.1101/2021.05.13.21257046; this version posted May 17, 2021. The copyright holder for this preprint (which was not certified by peer review) is the author/funder, who has granted medRxiv a license to display the preprint in perpetuity.

This article is a US Government work. It is not subject to copyright under 17 USC 105 and is also made available for use under a CCO license.

Figure

Figure 1. Beta coefficient means and 95\% upper/lower limits for all 4 models using predictors

for equipment, ranked in increasing order for mean of the frequentist approach for full

adherence. (a) assumes binary imputation. (b) assumes continuous imputation.

1A. Binary

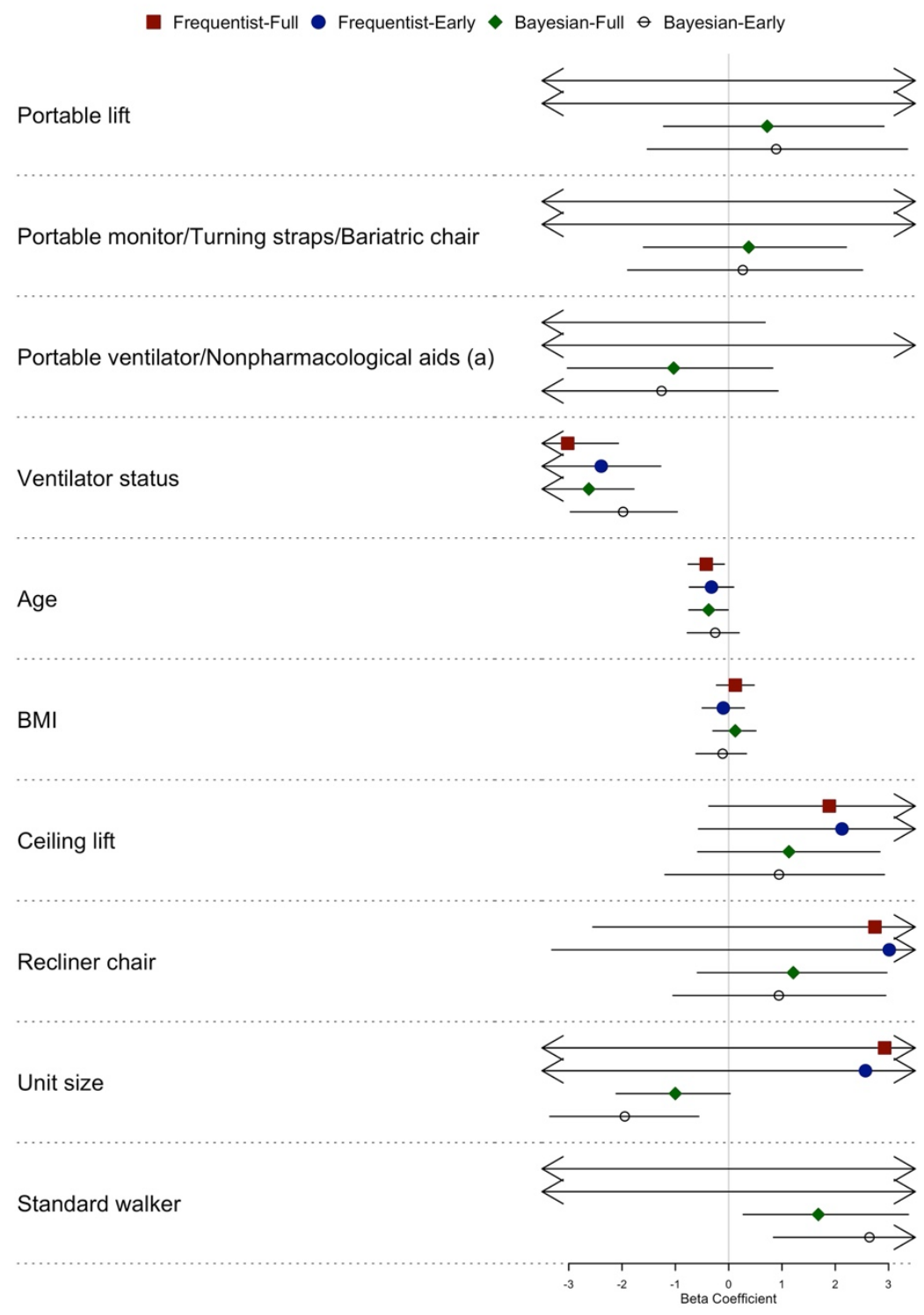


medRxiv preprint doi: https://doi.org/10.1101/2021.05.13.21257046; this version posted May 17, 2021. The copyright holder for this preprint (which was not certified by peer review) is the author/funder, who has granted medRxiv a license to display the preprint in perpetuity.

This article is a US Government work. It is not subject to copyright under 17 USC 105 and is also made available for use under a CCO license.

\section{B. Continuous}

- Frequentist-Full $\bullet$ Frequentist-Early $\bullet$ Bayesian-Full $\ominus$ Bayesian-Early

\section{Ventilator status}

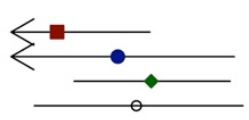

Oxygen tank

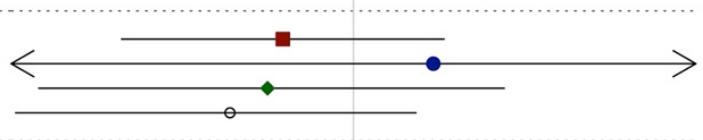

Recliner chair

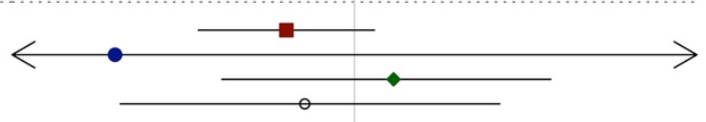

Age

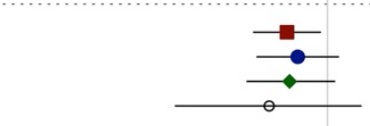

Oxygen tubing/PEEP valve

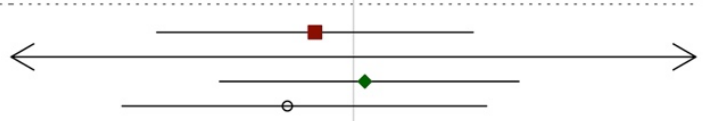

BMI

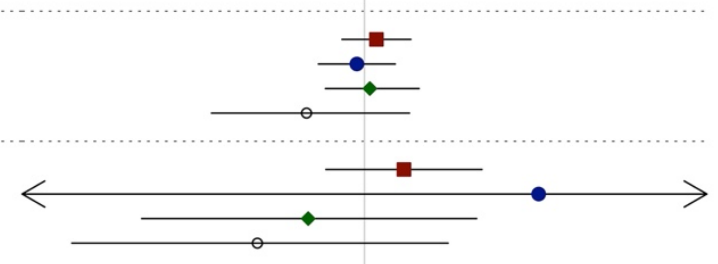

Specialty walker

Standard walker

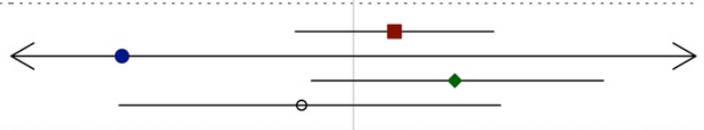

Unit size

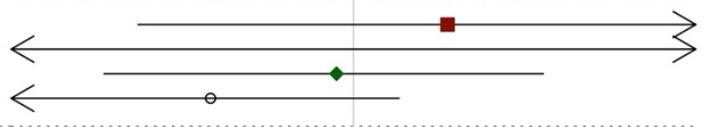

High back chair

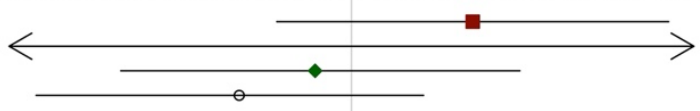

Canvas sling

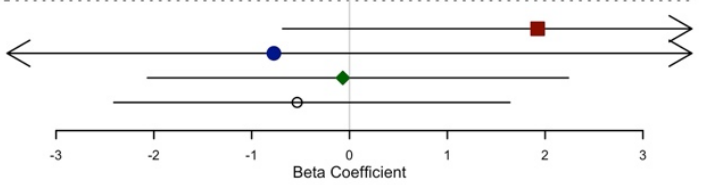


medRxiv preprint doi: https://doi.org/10.1101/2021.05.13.21257046; this version posted May 17, 2021. The copyright holder for this preprint (which was not certified by peer review) is the author/funder, who has granted medRxiv a license to display the preprint in perpetuity. This article is a US Government work. It is not subject to copyright under 17 USC 105 and is also made available for use under a CCO license.

\section{Tables}

Table 1: Descriptive statistics patient- and unit-level variables

\begin{tabular}{|c|c|c|c|c|}
\hline $\begin{array}{l}\text { Patient Variables } \\
(\mathrm{N}=105)\end{array}$ & $\begin{array}{c}\mathrm{N} \\
\text { (\% missing) }\end{array}$ & Mean (SD) & Median (IQR) & $\begin{array}{c}\text { Included in } \\
\text { Final } \\
\text { Analysis }\end{array}$ \\
\hline Age & $0(0)$ & $54(14)$ & $57(47,63)$ & Yes \\
\hline Height $(\mathrm{cm})$ & $6(6)$ & $171(12)$ & $173(164,178)$ & Yes \\
\hline Weight (kg) & $5(5)$ & $100(38)$ & $95(75,115)$ & Yes \\
\hline $\mathrm{BMI}$ & $6(6)$ & $35(17)$ & $32(25,38)$ & Yes \\
\hline Unit Variable $(\mathrm{N}=10)$ & $\begin{array}{c}\mathrm{N} \\
\text { (\% missing) }\end{array}$ & Mean (SD) & Median (IQR) & $\begin{array}{l}\text { Included in } \\
\text { Final } \\
\text { Analysis }\end{array}$ \\
\hline Unit Size $\left(m^{2}\right)$ & $10(0)$ & $2,088(1,981)$ & $\begin{array}{c}\text { 1,981 (1,103; } \\
3,109)\end{array}$ & Yes \\
\hline $\begin{array}{l}\text { Distance from HOB to } \\
\text { Bundle- } \\
\text { Enhancing Items }\end{array}$ & $\begin{array}{l}\mathrm{N} \text { units with } \\
\text { item } \\
\text { (\% missing) }\end{array}$ & $\begin{array}{l}\text { Mean (SD) } \\
\text { (meters) }\end{array}$ & $\begin{array}{l}\text { Median (IQR) } \\
\text { (meters) }\end{array}$ & $\begin{array}{l}\text { Included in } \\
\text { Final } \\
\text { Analysis }\end{array}$ \\
\hline Bag valve mask & $10(0)$ & $1.5(0.7)$ & $1.4(1.1,1.6)$ & \\
\hline Bariatric chair & $2(80)$ & $67.2(4.4)$ & $67.2(65.6,68.7)$ & Yes \\
\hline Canvas sling & $8(20)$ & $52.8(9.5)$ & $51.2(46.5,59)$ & Yes \\
\hline Ceiling lift & $7(30)$ & $1.3(0.3)$ & $1.3(1,1.7)$ & Yes \\
\hline Chart & $10(0)$ & $15.16(9.8)$ & $11.7(10,14.9)$ & \\
\hline Gait belt & $3(70)$ & $50.3(16.7)$ & $40.9(40.6,55.3)$ & \\
\hline High back chair & $5(50)$ & $50.4(21.5)$ & $64.4(30.7,66.8)$ & Yes \\
\hline Hover mat & $4(60)$ & $68.2(54.4)$ & $68.2(49,87.4)$ & \\
\hline Lift sheet & $4(60)$ & $17.7(1.1)$ & $17.7(17.3,18.1)$ & \\
\hline $\begin{array}{l}\text { Medication dispensing } \\
\text { system }\end{array}$ & $10(0)$ & $26.4(5.8)$ & $26.4(21.8,29.6)$ & \\
\hline Nonpharmacologic aids ${ }^{a}$ & $2(80)$ & $40.6(0.4)$ & $40.6(40.5,40.8)$ & Yes \\
\hline Oxygen tank & $10(0)$ & $42(13.2)$ & $42.4(30.3,49.8)$ & Yes \\
\hline Oxygen tubing & $10(0)$ & $50.2(14.6)$ & $50.5(43.5,57.5)$ & Yes \\
\hline PEEP valve & $10(0)$ & $50.2(14.6)$ & $50.5(43.5,57.5)$ & Yes \\
\hline Portable monitor & $2(80)$ & $50.8(18.7)$ & $50.8(44.2,57.5)$ & Yes \\
\hline Portable ventilator & $2(80)$ & $46.1(2)$ & $46.1(45.4,46.8)$ & Yes \\
\hline Radio & $1(90)$ & 0.9 (NA) & $0.9(0.9,0.9)$ & \\
\hline Recliner chair & $7(30)$ & $11.2(11.9)$ & $3.9(2.4,18.4)$ & Yes \\
\hline Sit-to-Stand & $2(80)$ & $66.8(0)$ & $66.8(66.8,66.8)$ & \\
\hline Sling lift & $8(20)$ & $66(1.4)$ & $66.8(65.6,66.8)$ & Yes \\
\hline Specialty walker ${ }^{\mathrm{b}}$ & $6(40)$ & $80.4(67.1)$ & $65.9(46.4,69.5)$ & Yes \\
\hline Standard walker & $9(10)$ & $55.1(17.2)$ & $66.8(47.5,67.4)$ & Yes \\
\hline Standing lift & $3(70)$ & $66(1.4)$ & $66.8(65.6,66.8)$ & Yes \\
\hline Stretch band & $2(80)$ & $40.6(0.4)$ & $40.6(40.5,40.8)$ & \\
\hline
\end{tabular}


medRxiv preprint doi: https://doi.org/10.1101/2021.05.13.21257046; this version posted May 17, 2021. The copyright holder for this preprint

(which was not certified by peer review) is the author/funder, who has granted medRxiv a license to display the preprint in perpetuity.

This article is a US Government work. It is not subject to copyright under 17 USC 105 and is also made available for use under a CCO license.

\begin{tabular}{|l|c|c|c|c|}
\hline Turning strap & $2(80)$ & $50.3(9.8)$ & $50.3(46.8,53.7)$ & Yes \\
\hline
\end{tabular}

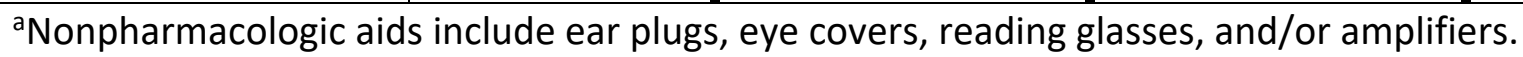

${ }^{b}$ walker that allows ambulation with fewer staff members; may include integrated features for oxygen tanks, portable ventilator/monitor, telescoping IV pole, seat flaps, leaning bar, among other features

Abbreviations: $\mathrm{BMI}=$ body mass index, $\mathrm{m}^{2}=$ square meters, $\mathrm{HOB}=$ head of bed, $\mathrm{IQR}=$ interquartile range, $\mathrm{PEEP}=$ positive end expiratory pressure, $\mathrm{SD}=$ standard deviation 
medRxiv preprint doi: https://doi.org/10.1101/2021.05.13.21257046; this version posted May 17, 2021. The copyright holder for this preprint (which was not certified by peer review) is the author/funder, who has granted medRxiv a license to display the preprint in perpetuity. This article is a US Government work. It is not subject to copyright under 17 USC 105 and is also made available for use under a CCO license.

Table 2. Comparison of best-fit models using AIC (Frequentist) or WAIC (Bayesian) values.

\begin{tabular}{|c|c|c|c|c|c|c|}
\hline \multirow{3}{*}{$\begin{array}{l}\text { Approach } \\
\text { Predictors }\end{array}$} & \multirow{2}{*}{\multicolumn{2}{|c|}{ Frequentist }} & \multicolumn{4}{|c|}{ Bayesian } \\
\hline & & & \multicolumn{2}{|c|}{ Uninformative Priors } & \multicolumn{2}{|c|}{ Informative Priors } \\
\hline & Continuous & Binary & Continuous & Binary & Continuous & Binary \\
\hline \multicolumn{7}{|l|}{ Outcome } \\
\hline Full bundle $(n=751)$ & 657.8 & $655.9 *$ & 634.18 & $626.04^{*}$ & 643.27 & 644.85 \\
\hline Early mobility $(n=748)$ & 450.4 & 448.9* & 432.72 & $428.21 *$ & 431.43 & 431.79 \\
\hline
\end{tabular}

Note: Bolded asterisk $(*)$ indicates lowest (best) value for each outcome/approach combination.

Table 3. Beta coefficients for parameters of best-fit models examining adherence with full bundle.

\begin{tabular}{|c|c|c|c|c|}
\hline \multirow{2}{*}{$\begin{array}{l}\text { Approach } \\
\text { Predictors }\end{array}$} & \multicolumn{2}{|c|}{$\begin{array}{c}\text { Frequentist } \\
\text { Mean (standard deviation) }\end{array}$} & \multicolumn{2}{|c|}{$\begin{array}{c}\text { Bayesian } \\
\text { Mean (2.5\% HPD, 97.5\% HPD) }\end{array}$} \\
\hline & Continuous & Binary & Continuous & Binary \\
\hline \multicolumn{5}{|l|}{ Daily Variable } \\
\hline Ventilator status & $-3.0(0.5) * * *$ & $-3.0(0.5) * * *$ & $-2.1(-2.9,-1.3)^{*}$ & $-2.6(-3.5,-1.8)^{*}$ \\
\hline \multicolumn{5}{|l|}{ Patient Variables } \\
\hline Age & $-0.4(0.2)^{*}$ & $-0.4(0.2)^{*}$ & $-0.4(-0.8,0.07)$ & $-0.4(-0.7,-0.01)^{*}$ \\
\hline BMI & $0.1(0.2)$ & $0.1(0.2)$ & $0.05(-0.4,0.6)$ & $0.1(-0.3,0.5)$ \\
\hline \multicolumn{5}{|l|}{ Unit Variables } \\
\hline Unit size & $1.0(1.6)$ & $2.9(3.5)$ & $-0.2(-2.5,1.9)$ & $-1.0(-2.1,0.03)$ \\
\hline Canvas sling & $1.9(1.3)$ & $\mathrm{n} / \mathrm{a}$ & $-0.07(-2.1,2.2)$ & $\mathrm{n} / \mathrm{a}$ \\
\hline Ceiling lift & $\mathrm{n} / \mathrm{a}$ & $1.9(1.2)$ & $\mathrm{n} / \mathrm{a}$ & $1.1(-0.6,2.8)$ \\
\hline High back chair & $1.2(1.0)$ & $\mathrm{n} / \mathrm{a}$ & $-0.4(-2.4,1.7)$ & $\mathrm{n} / \mathrm{a}$ \\
\hline Oxygen tank & $-0.7(0.8)$ & $\mathrm{n} / \mathrm{a}$ & $-0.9(-3.2,1.5)$ & $\mathrm{n} / \mathrm{a}$ \\
\hline $\begin{array}{l}\text { Oxygen tubing/PEEP } \\
\text { valve }\end{array}$ & $-0.4(0.8)$ & $\mathrm{n} / \mathrm{a}$ & $0.1(-1.4,1.7)$ & $\mathrm{n} / \mathrm{a}$ \\
\hline Portable lift & $\mathrm{n} / \mathrm{a}$ & $-12.0(11.6)$ & $\mathrm{n} / \mathrm{a}$ & $0.7(-1.2,2.9)$ \\
\hline $\begin{array}{l}\text { Portable } \\
\text { monitor/Turning } \\
\text { straps/Bariatric chair }\end{array}$ & $\mathrm{n} / \mathrm{a}$ & $-8.7(8.4)$ & $\mathrm{n} / \mathrm{a}$ & $0.4(-1.6,2.2)$ \\
\hline $\begin{array}{l}\text { Portable ventilator/ } \\
\text { Nonpharmacologic aids }\end{array}$ & $\mathrm{n} / \mathrm{a}$ & $-5.7(3.3)$ & $\mathrm{n} / \mathrm{a}$ & $-1.0(-3.0,0.8)$ \\
\hline Recliner chair & $-0.7(0.5)$ & $2.7(2.7)$ & $0.4(-1.4,2.0)$ & $1.2(-0.6,3.0)$ \\
\hline Specialty walker & $0.4(0.4)$ & $\mathrm{n} / \mathrm{a}$ & $-0.6(-2.3,1.1)$ & $\mathrm{n} / \mathrm{a}$ \\
\hline Standard walker & $0.4(0.5)$ & $-5.3(4.7)$ & $1.0(-0.4,2.6)$ & $1.7(0.3,3.4)^{*}$ \\
\hline
\end{tabular}

Note: *** p-value <0.001; * p-value < 0.05 (Frequentist) or 95\% HPD excludes 0 (Bayesian).

Both Bayesian approaches assume uninformative priors. 
medRxiv preprint doi: https://doi.org/10.1101/2021.05.13.21257046; this version posted May 17, 2021. The copyright holder for this preprint (which was not certified by peer review) is the author/funder, who has granted medRxiv a license to display the preprint in perpetuity. This article is a US Government work. It is not subject to copyright under 17 USC 105 and is also made available for use under a CCO license.

Table 4. Beta coefficients for parameters of best-fit models examining adherence with early mobility component of bundle.

\begin{tabular}{|c|c|c|c|c|}
\hline \multirow{2}{*}{$\begin{array}{l}\text { Approach } \\
\text { Predictors }\end{array}$} & \multicolumn{2}{|c|}{$\begin{array}{c}\text { Frequentist } \\
\text { Mean (standard deviation) }\end{array}$} & \multicolumn{2}{|c|}{$\begin{array}{c}\text { Bayesian } \\
\text { Mean (2.5\% HPD, } 97.5 \% \text { HPD) }\end{array}$} \\
\hline & Continuous & Binary & Continuous & Binary \\
\hline \multicolumn{5}{|l|}{ Daily Variable } \\
\hline Daily ventilator status & $-2.4(0.6) * * *$ & $-2.4(0.6)^{* * *}$ & $-2.2(-3.3,-1.1)^{*}$ & $-2.0(-3.0,-1.0)^{*}$ \\
\hline \multicolumn{5}{|l|}{ Patient Variables } \\
\hline Age & $-0.3(0.2)$ & $-0.3(0.2)$ & $-0.6(-1.6,0.3)$ & $-0.3(-0.8,0.2)$ \\
\hline BMI & $-0.1(0.2)$ & $-0.1(0.2)$ & $-0.6(-1.6,0.5)$ & $-0.1(-0.6,0.3)$ \\
\hline \multicolumn{5}{|l|}{ Unit Variables } \\
\hline Unit size & $-9.5(599.1)$ & $2.6(4.1)$ & $-1.5(-3.7,0.5)$ & $-1.9(-3.4,-0.6)^{*}$ \\
\hline Canvas sling & $-0.8(133.7)$ & $\mathrm{n} / \mathrm{a}$ & $-0.5(-2.4,1.6)$ & $\mathrm{n} / \mathrm{a}$ \\
\hline Ceiling lift & $\mathrm{n} / \mathrm{a}$ & $2.1(1.4)$ & $\mathrm{n} / \mathrm{a}$ & $0.9(-1.2,2.9)$ \\
\hline High back chair & $-4.9(379.9)$ & $\mathrm{n} / \mathrm{a}$ & $-1.1(-3.2,0.7)$ & $\mathrm{n} / \mathrm{a}$ \\
\hline Oxygen tank & $0.8(71.9)$ & $\mathrm{n} / \mathrm{a}$ & $-1.3(-3.5,0.6)$ & $\mathrm{n} / \mathrm{a}$ \\
\hline $\begin{array}{l}\text { Oxygen tubing/PEEP } \\
\text { valve }\end{array}$ & $4.1(273.6)$ & $\mathrm{n} / \mathrm{a}$ & $-0.7(-2.4,1.4)$ & $\mathrm{n} / \mathrm{a}$ \\
\hline Portable lift & $\mathrm{n} / \mathrm{a}$ & $-28.7(65.4)$ & $\mathrm{n} / \mathrm{a}$ & $0.9(-1.5,3.4)$ \\
\hline $\begin{array}{l}\text { Portable } \\
\text { monitor/Turning } \\
\text { straps/Bariatric chair }\end{array}$ & $\mathrm{n} / \mathrm{a}$ & $-25.4(65.3)$ & $\mathrm{n} / \mathrm{a}$ & $0.3(-1.9,2.5)$ \\
\hline Portable ventilator & $\mathrm{n} / \mathrm{a}$ & $-21.9(65.6)$ & $\mathrm{n} / \mathrm{a}$ & $-1.3(-3.7,0.9)$ \\
\hline Recliner chair & $-2.4(98.0)$ & $3.0(3.2)$ & $-0.5(-2.4,1.5)$ & $0.9(-1.0,2.9)$ \\
\hline Specialty walker & $1.8(88.4)$ & $\mathrm{n} / \mathrm{a}$ & $-1.1(-3.0,0.9)$ & $\mathrm{n} / \mathrm{a}$ \\
\hline Standard walker & $-2.4(148.4)$ & $22.6(65.4)$ & $-0.5(-2.4,1.5)$ & $2.6(0.8,4.7)^{*}$ \\
\hline
\end{tabular}

Note: $* * *$ p-value $<0.001 ; *$-value $<0.05$ (Frequentist) or $95 \%$ HPD excludes 0 (Bayesian). Bayesian approaches assume uninformative priors for binary predictors and weakly-informative priors for continuous predictors. 
medRxiv preprint doi: https://doi.org/10.1101/2021.05.13.21257046; this version posted May 17, 2021. The copyright holder for this preprint (which was not certified by peer review) is the author/funder, who has granted medRxiv a license to display the preprint in perpetuity. This article is a US Government work. It is not subject to copyright under 17 USC 105 and is also made available for use under a CCO license.

Author Contributions: Drs. Werthman, Jeffery, Dietrich, and Boehm had full access to all of the data in the study and take responsibility for the integrity of the data and the accuracy of the data analysis.

Concept and design: Werthman, Jeffery, Mion, Boehm

Acquisition, analysis, or interpretation of data: Werthman, Jeffery, Boehm, Dietrich, Mion

Drafting of the manuscript: Werthman, Jeffery, Danesh, Boehm

Critical revision of the manuscript for important intellectual content: All

Statistical analysis: Werthman, Jeffery, Dietrich

Obtained funding: Boehm

Administrative, technical, or material support: Jeffery, Boehm

Supervision: Dietrich, Boehm

Conflict of Interest Disclosures: $L M B$ is currently receiving grant funding from the National Heart, Lung, and Blood Institute (\#K12HL137943-01). ADJ received support for this work from the Agency for Healthcare Research and Quality (AHRQ) and the Patient-Centered Outcomes Research Institute (PCORI) under award number K12 HS026395. JW and ADJ received support from the resources and use of facilities at the Department of Veterans Affairs, Tennessee Valley Healthcare System. The content is solely the responsibility of the authors and does not necessarily represent the official views of AHRQ, PCORI, the Department of Veterans Affairs, or the United States Government. No other disclosures were reported.

Funding/Support: This project was funded by an American Association of Critical-Care NursesSigma Theta Tau International Critical Care Grant (\#20170) and the Vanderbilt Institute for Clinical and Translational Research (UL1 TR000445 from National Center for Advancing Translational Sciences/National Institutes of Health).

Role of the Funder/Sponsor: The funders had no role in the design and conduct of the study; collection, management, analysis, and interpretation of the data; preparation, review, or approval of the manuscript; and decision to submit the manuscript for publication.

Additional Contributions: The authors would like to thank Dr. David Schlueter for contributing his knowledge and expertise during the technical design of the Bayesian modeling. 
medRxiv preprint doi: https://doi.org/10.1101/2021.05.13.21257046; this version posted May 17, 2021. The copyright holder for this preprint

(which was not certified by peer review) is the author/funder, who has granted medRxiv a license to display the preprint in perpetuity.

This article is a US Government work. It is not subject to copyright under 17 USC 105 and is also made available for use under a CCO license.

\section{Supplementary Material}

eFigure 1. Highest density interval ridge plot representing beta coefficient estimates in the full bundle adherence Bayesian model with uninformative priors and binary predictors.

eFigure 2. Highest density interval ridge plot representing beta coefficient estimates in the full bundle adherence Bayesian model with uninformative priors and continuous predictors.

efigure 3. Highest density interval ridge plot representing beta coefficient estimates in the early mobility bundle adherence Bayesian model with uninformative priors and binary predictors.

eFigure 4. Highest density interval ridge plot representing beta coefficient estimates in the early mobility bundle adherence Bayesian model with weakly informative priors and continuous predictors.

eTable 1 Equipment variable inclusion/exclusion following data-driven redundancy analysis with input from subject matter experts. 
medRxiv preprint doi: https://doi.org/10.1101/2021.05.13.21257046; this version posted May 17, 2021. The copyright holder for this preprint (which was not certified by peer review) is the author/funder, who has granted medRxiv a license to display the preprint in perpetuity.

This article is a US Government work. It is not subject to copyright under 17 USC 105 and is also made available for use under a CCO license.

\section{Supplementary Figures}

eFigure 1. Highest density interval ridge plot representing beta coefficient estimates in the full bundle adherence Bayesian model with uninformative priors and binary predictors.

Portable ventilator/Nonpharmacological aids+

Ventilator status

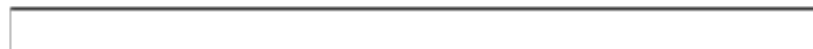

Portable monitor/Turning straps/Bariatric chair

Unit size

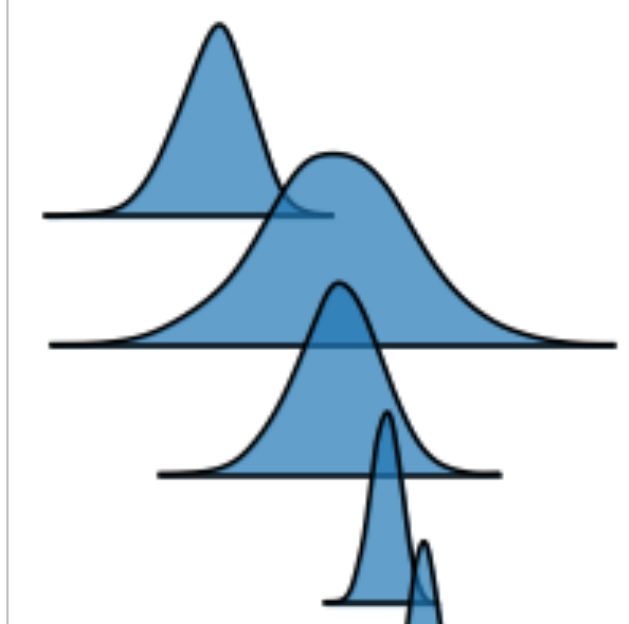

BMI

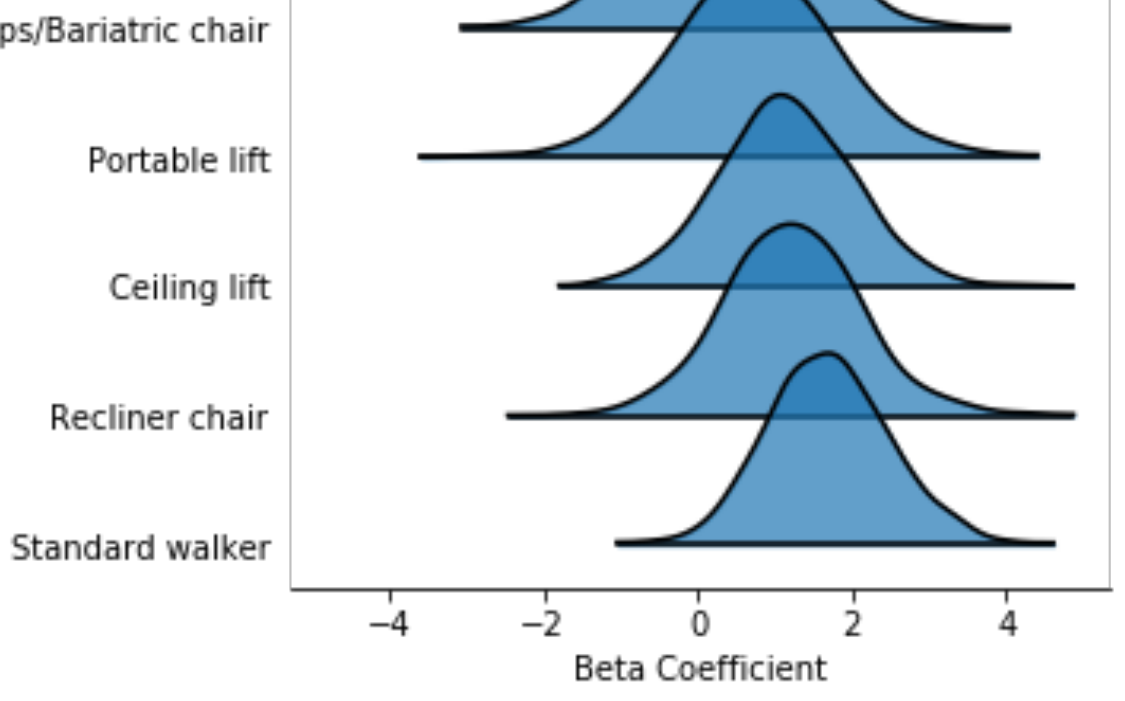


medRxiv preprint doi: https://doi.org/10.1101/2021.05.13.21257046; this version posted May 17, 2021. The copyright holder for this preprint (which was not certified by peer review) is the author/funder, who has granted medRxiv a license to display the preprint in perpetuity.

This article is a US Government work. It is not subject to copyright under 17 USC 105 and is also made available for use under a CCO license.

eFigure 2. Highest density interval ridge plot representing beta coefficient estimates in the full bundle adherence Bayesian model with uninformative priors and continuous predictors.

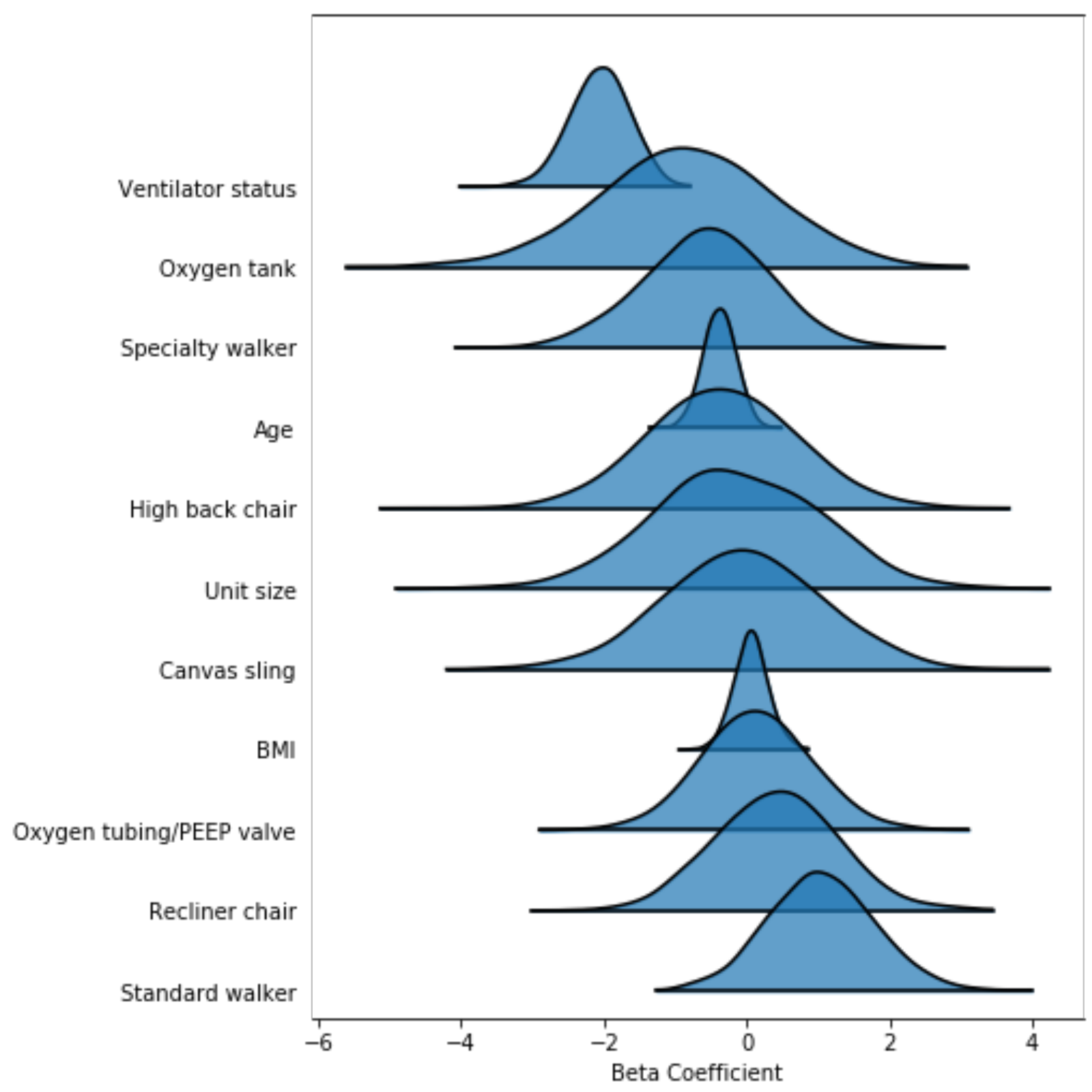


medRxiv preprint doi: https://doi.org/10.1101/2021.05.13.21257046; this version posted May 17, 2021. The copyright holder for this preprint (which was not certified by peer review) is the author/funder, who has granted medRxiv a license to display the preprint in perpetuity.

This article is a US Government work. It is not subject to copyright under 17 USC 105 and is also made available for use under a CCO license.

eFigure 3. Highest density interval ridge plot representing beta coefficient estimates in the early mobility bundle adherence Bayesian model with uninformative priors and binary predictors.

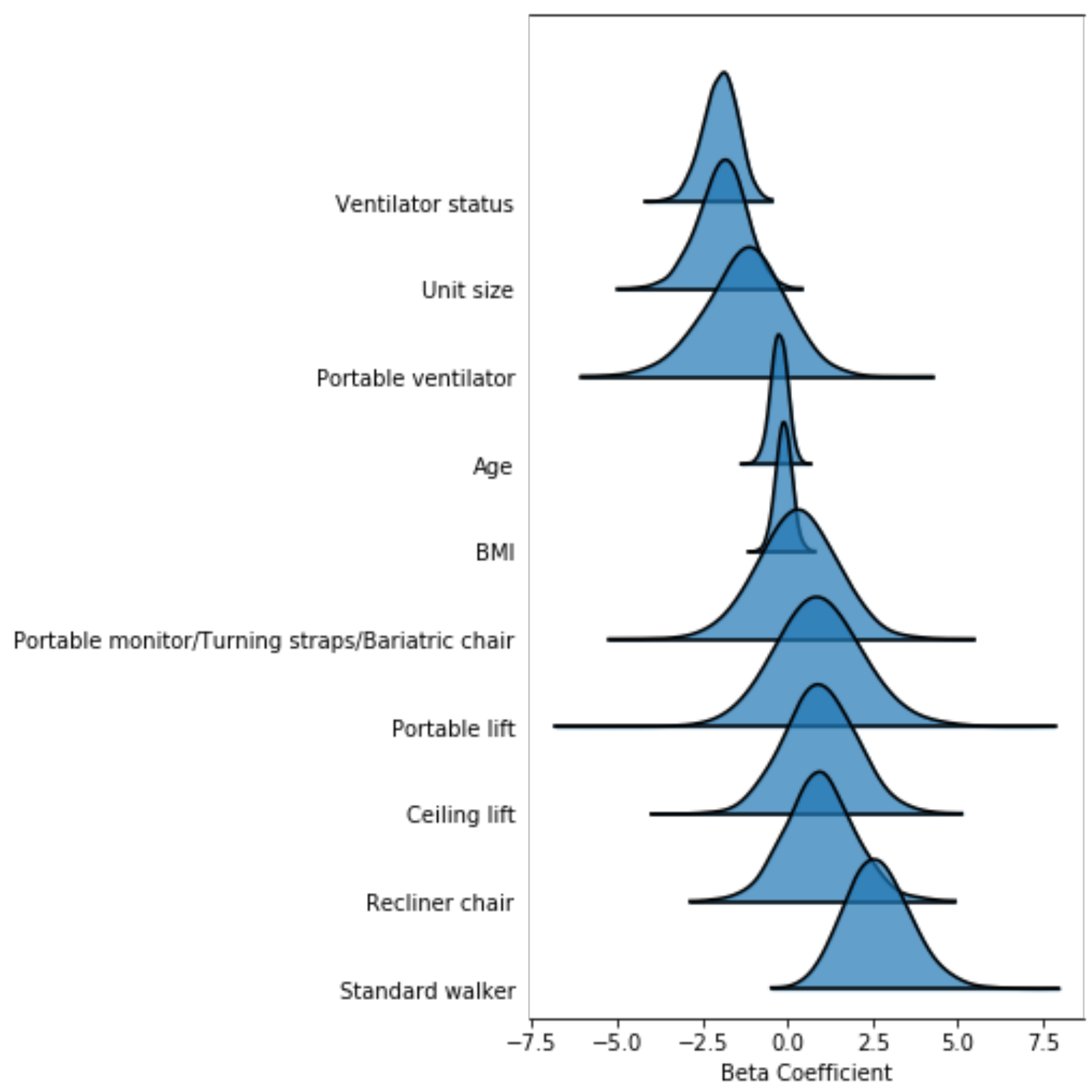


medRxiv preprint doi: https://doi.org/10.1101/2021.05.13.21257046; this version posted May 17, 2021. The copyright holder for this preprint (which was not certified by peer review) is the author/funder, who has granted medRxiv a license to display the preprint in perpetuity.

This article is a US Government work. It is not subject to copyright under 17 USC 105 and is also made available

eFigure 4. Highest density interval ridge plot representing beta coefficient estimates in the early mobility bundle adherence Bayesian model with weakly informative priors and continuous predictors.

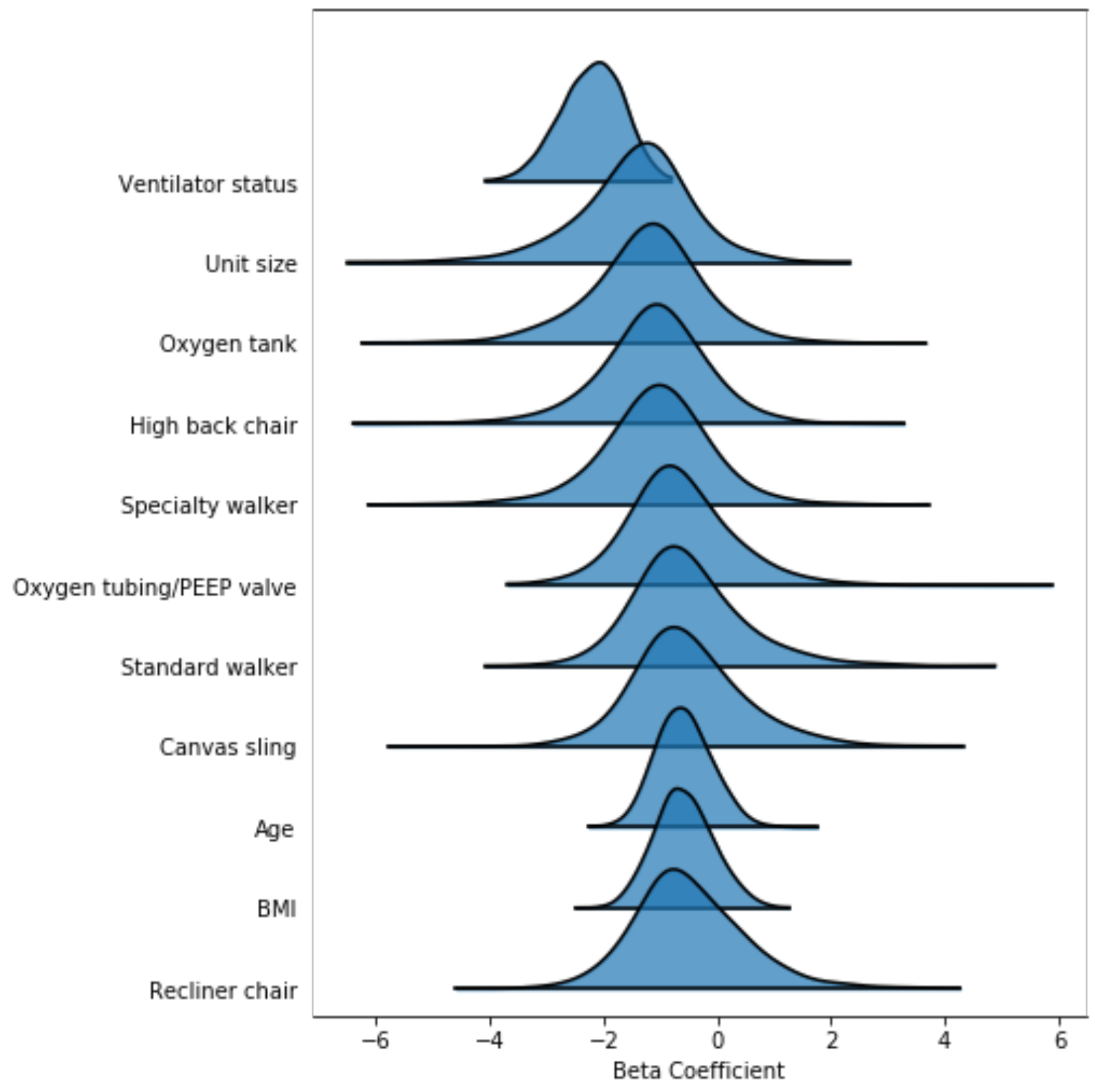


eTable 1 Equipment variable inclusion/exclusion following data-driven redundancy analysis with input from subject matter experts.

\begin{tabular}{|c|c|c|c|}
\hline & $\begin{array}{c}\text { Included in } \\
\text { Binary } \\
\text { Model? }\end{array}$ & $\begin{array}{c}\text { Included in } \\
\text { Continuous } \\
\text { Model? }\end{array}$ & Rationale for Variable Exclusion \\
\hline Bag valve mask & & & $\begin{array}{l}\text { Binary: present on all units, no variation } \\
\text { Continuous: if present, always inside room }\end{array}$ \\
\hline Bariatric chair & Yes & & $\begin{array}{c}\text { Binary: identical to \& combined with Turning straps \& Portable monitor } \\
\text { Continuous: insufficient variation }\end{array}$ \\
\hline Canvas sling & & Yes & Binary: redundant with several variables \\
\hline Ceiling lift & Yes & & Continuous: if present, always inside room \\
\hline Chart & & & $\begin{array}{c}\text { Binary: present on all units, no variation } \\
\text { Continuous: outcome was adherence to activity, not documentation }\end{array}$ \\
\hline Gait belt & & & Both: redundant with several variables \\
\hline High back chair & & Yes & Binary: redundant with several variables \\
\hline Hover mat & & & Both: redundant with several variables \\
\hline Lift sheet & & & Both: redundant with several variables \\
\hline $\begin{array}{l}\text { Medication } \\
\text { dispensing system }\end{array}$ & & & $\begin{array}{c}\text { Binary: present on all units, no variation } \\
\text { Continuous: redundant with several variables }\end{array}$ \\
\hline $\begin{array}{l}\text { Nonpharmacologic } \\
\text { aids }^{\mathrm{a}}\end{array}$ & Yes & & Continuous: insufficient variation \\
\hline Oxygen tank & & Yes & Binary: present on all units, no variation \\
\hline Oxygen tubing & & Yes & $\begin{array}{c}\text { Binary: present on all units, no variation } \\
\text { Continuous : identical to \& combined with PEEP valve }\end{array}$ \\
\hline PEEP valve & & Yes & $\begin{array}{l}\text { Binary: present on all units, no variation } \\
\text { Continuous: identical to \& combined with Oxygen tubing }\end{array}$ \\
\hline Portable monitor & Yes & & $\begin{array}{l}\text { Binary: identical to \& combined with Bariatric chair \& Turning straps } \\
\text { Continuous: insufficient variation }\end{array}$ \\
\hline Portable ventilator & Yes & & Continuous: insufficient variation \\
\hline Radio & & & $\begin{array}{l}\text { Binary: redundant with several variables } \\
\text { Continuous: insufficient variation }\end{array}$ \\
\hline Recliner chair & Yes & Yes & \\
\hline Sit-to-Stand & & & $\begin{array}{l}\text { Binary: redundant with several variables } \\
\text { Continuous: insufficient variation }\end{array}$ \\
\hline Sling lift & Yes & & Binary: identical to \& combined with Standing lift \\
\hline
\end{tabular}




\begin{tabular}{|l||l|l|c|}
\hline & & & Continuous: insufficient variation \\
\hline Specialty walker & & Yes & Binary: redundant with several variables \\
\hline Standard walker & Yes & Yes & $\begin{array}{c}\text { Binary: identical to \& combined with Sling lift } \\
\text { Continuous: insufficient variation }\end{array}$ \\
\hline Standing lift & Yes & & $\begin{array}{c}\text { Binary: redundant with several variables } \\
\text { Continuous: insufficient variation }\end{array}$ \\
\hline Stretch band & & & $\begin{array}{c}\text { Binary: identical to \& combined with Bariatric chair \& Portable monitor } \\
\text { Continuous: redundant with several variables }\end{array}$ \\
\hline Turning straps & Yes & & \\
\hline
\end{tabular}

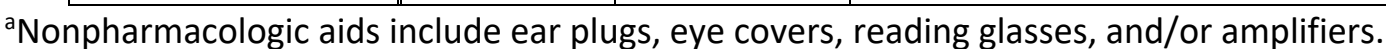

Abbreviations: $\mathrm{PEEP}=$ positive end expiratory pressure 